$\begin{array}{ccc} & \\ 3 & \text { Journal of Stroke Research } \\ \text { (JSR) }\end{array}$

\title{
Management of Post Bilateral Pontine Haemorrhage with Ayurveda
}

\author{
Kajaria Divya $^{1 *}$ \\ ${ }^{1}$ Assistant Professor, Department of Kayachikitsa, C.B.P.A.C.S, New Delhi
}

\begin{abstract}
Background and Purpose. This case report documents the management of residual paralysis due to a rare and fatal disease - hemorrhagic leukoencephalitis with Ayurveda. The purpose of this report is to illustrate the role of Ayurvedic treatment methodology for management of such neurological disorders.

*Correspondence to Author:

Kajaria Divya

Case Description: Mrs. PM was a 31 year old lady who suffered from an attack of acute hemorrhagic leukoencephalitis after her second delivery. She had left hemiplegia with right sided LMN facial palsy with nystagmus and loss of control of posture and Assistant Professor, Department of Kayachikitsa, C.B.P.A.C.S, New whole-limb movements. Some residual ability to use the right hand and fingers remained, provided the trunk and right upper arm were stabilized. Her cognitive power remains undiminished. Delhi.

Computed tomographic scans verified acute bilateral paramedian pontine hemorrhage with intraventricular extension. It also Accepted 22 August 2016; pubshowed chronic infarcts in bilateral external capsules. Discussion. lished 22 August 2016.

15 days treatment with Ayurvedic medicines and Panchakarma procedures including Nasya and Tarapan therapies showed significant improvement in nystagmus, postural abnormalities and whole - body movement.

E-mail: divyakajaria@gmail.com

How to cite this article:

Kajaria Divya. Management of Post Bilateral Pontine Haemorrhage with Ayurveda. Journal of Stroke Research, 2016,1(1): 0001-0012.

\section{eSciencePublisher 。 Website: http://escipub.com/} eSciPub LLC, Houston, TX USA.

Keywords:

Nasya, Tarpana, Nystagmus, Ataxia
\end{abstract}




\section{Case Description \\ Patient History}

Mrs. PM was a right handed 31 year old female presented with the complaints of left sided hemiparesis and right sided mild LMN type facial palsy, ataxia, slurred speech, blurred vision (diplopia) with difficulty in accomplishing the coordinated movements. She had $\mathrm{H} / \mathrm{O}$ of delivering a baby boy on 9/08/2014 at 4am in a hospital nearby to her home and at $11 \mathrm{am}$ she had an acute attack of left sided upper and lower limb weakness associated with slurred speech, altered sensorium and right sided facial weakness. MRI Brain conducted at that time reveals acute bilateral pontine haemorrhage. As her condition was not stabilised and get worsen with life threatening neurological condition she was shifted to higher centre for proper management. In higher centre she was admitted in ICU for General Condition Monitoring (GCS). As she had accelerated hypertension she had given infusion of Nitoglycerine (NTG). She was evaluated for secondary cause of haemorrhagic stroke in young. Blood investigation revealed raised TLC count and serum procalcitonin assay suggestive of sepsis for which she had received broad spectrum antibiotics coverage. Echocardiography showed no no Left Ventricular Regional Wall Motion Abnormality (LV RWMA), Left Ventricular Ejection Fraction (LVEF) $55 \%$, Mild Mitral Regurgitation (MR), Trace Tricuspid Regurgitation (TR), no clot seen. Her procoagulant work for lupus anticoagulant was negative. CSF study done showed cells count 20, protein 41 and glucose 50 . Her ESR and CRP are significantly high. Considering the possibility of ongoing vasculitis she had also treated with methylprednisolon. Her serum fibrinogen and Haptoglobin levels were normal omitted the possibility of intravascular and extravascular haemorrhage. At that time patient had diminished vision due to hypertensive retinopathy. CT Brain Plain mobile on 10/08/2014 showed acute bilateral pontine haemorrhage with intraventricular extension. Chronic infarcts in bilateral external capsules. MRI Brain (Contrast) dated: 12/08/2014 : Study reveals hemorrhage in dorsal pons with moderate odema and expansion of pons dorsally resulting in partial effacement of $4^{\text {th }}$ ventricular calibre. Multifocal asymmetrical faint area of T2 FLAIR hyperintensity are seen in bilateral corona radiate, posterior putamina and external capsules. Focal linear cortical FLAIR hyperintensity is also seen in the mid splenium of corpus callosum. On post- contrast imaging, no abnormal enhancement is seen in these areas. Possibilities to be considered are haemorrhagic haemorrhagic Acute Disseminated Encephalomyelitis (ADEM)/ haemorrhagic leukoencephalitis and posterior reversible encephalopathy syndrome with bleed. (Fig. 1 A) UItrasound whole abdomen on 11/08/2014 reveals partially distended Gall Bladder and mild splenomegaly.

\section{At the time of admission:}

Higher Functions: She is well oriented to time, person and place. Her mental status is depressed and she starts crying frequently.

Pupil: Pin point pupil, pupil are unreactive to both direct and consensual light. Confrontation test showed visual acuity in all direction with bilateral central scotoma. There is vertical gaze nystagmus with right sided lateral divergent squint. Extraocular movement is not restricted and there is no ptosis but there is restricted conjugate gaze.

Speech: There is mild ataxic dysarthria due to lateral deviation of tongue, though audition and oral comprehension are normal, and no aphasia or signs of cognitive impairment are evident.

Motor functions: Muscle power: Left UL $3 / 5$, LL $5 / 5$, Right UL 4+/5, LL $5 / 5$

Muscle Nutrition: There is no atrophy, hypertrophy or dystrophy.

Muscle Tone: Tone is normal with no rigidity, spasticity or flaccidity.

Reflexes: Superficial reflexes- abdominal = absent

Deep Tendon reflexes: Upper limbs:

Bicep- Right $=+$ Left $=+$

Tricep- Right $=+$ Left $=+$ Supinator Right $=+$ Left $=+$

Lower Limbs:

Knee jerk Right $=+\quad$ Left $=-$ ve

Ankle jerk Right $=-$ ve $\quad$ Left $=-$ ve

Planter reflex: Right - equivocal, left - mild extensor (as there is extension of all four finger but fanning of fingers and movement of toe preceded by it is not present).

Other Signs: There is presence of apraxia ( she is not able to perform coordinated voluntary movements like combing, bearing sleepers etc.), but there is no agraphasthesia (she recognised the letter written on her palm with closed eyes, she has education- 
al qualification upto graduation), asterognosia (she is able to recognise three dimensional structures with closed eyes like remote, mobile, etc), dyslexia and agnosia (she can discriminate the things and able to distinguish good and bad). There is mild dysgraphia with poorly formed words but the sequence of words and coherent is maintained with no micrographia.

Cerebellar Signs: like dysdiadochokinesia (tested by finger-nose test), ataxia (she is not able to maintain standing erect posture for a single second and fell toward left side firstly and then forwardly), and dysmetria (she is not able to judge the distance between her hands and bed and therefore can't able to put hands correctly on bed for support while trying to sit down).

Horizontal eye movements and conjugated gaze were severely restricted as a result of bilateral abducent nerve paralysis. She has mild right sided facial weakness (in her previous medical reports right sided LMN type facial paralysis was reported ), at present wrinkling and frowning are preserved, nasolabial fold is also not deviated with mild deviation of angle of mouth to the left side her tongue is also deviated to the right side due to unopposed action of contralateral genioglossus. She has no complaint of dysphagia and her respirations is normal. Tactile discrimination and sensation of position of limbs are normal. Audition and oral comprehension were normal, and no aphasia or signs of cognitive impairment were evident. She responded to questions and commands correctly and without delay, and she called for assistance when necessary. Her emotional and social responses were appropriate. She became understandably frustrated with her inability to successfully perform some tasks but exhibited good abstract thinking and problem-solving abilities in devising alternative strategies.

\section{Posture and Whole-Body Movements}

Neuronal damage associated with the hemorrhage in the medial pontine tegmentum resulted in severe deficits of control of posture, balance, and locomotion. Rolling and transitions from sitting to supine postures were poorly coordinated, and they were not accompanied by sequential eye, head, or trunk movements and protective assistance of the upper extremities. She was unable to sit unsupported, and attempts to use her arms or legs for postural support were ineffective. During transitions from sitting to standing, her hips and knees were poorly coordinated as evidenced by high variability in the temporal sequence of hip and knee extension. Postural align- ment and the ability to remain upright while sitting or standing deteriorated further with the eyes closed.

\section{Independent Limb Movements}

Despite severe postural deficits of head, trunk, and limb girdle, she made relatively good use of both upper limbs provided the trunk and limbs were appropriately stabilized. Though the fine movement of fingers and thumb are compromised as holding a mug or combing, etc cant be carried out smoothly and she need assistant for these work. Thus, some functional use of the fingers remained, yet skillful manipulation of objects with either hand was poor. Her voluntary limb movements were poorly integrated with posture.

\section{Cognition.}

Cognition ability of the patient was preserved though emotional instability was present. She frequently starts crying as she was not able to look after her too kids (youngerwas one year old and elder girl was 5 year old) moreover her husband ignorance and bad behaviour of her in-laws made her depressed.

\section{Somatosensory responsiveness}

Examination of somatosensory responsiveness included testing discriminative touch, pain and temperature sensation, and kinesthesia. Discriminative touch and pain and temperature sensation were intact in the right extremities and were decreased in the left extremities. Kinesthesia was intact in the right extremities and absent in the left extremities.

\section{Muscle function.}

Muscle tone (ie, resistance to passive stretch) was examined by observing trunk and extremity posture, by palpation, and by monitoring resistance to imposed movements of extremity joints. Tone appeared to be decreased in muscles of the trunk and left extremities.She was able to hold her knee joint in a flexed position and in an extended position against maximal pressure (5/5) and her ankle joint in a dorsiflexed position against minimal pressure (3+ to 4-/5) bilaterally. On the right, she was able to hold her shoulder joint in a flexed position and in an abducted position against moderate pressure (4/5). She was able to hold her elbow joint against maximal pressure (5/5) and her wrist and finger joints against minimal pressure (3+ to 4-/5). On the left, she was able to hold her shoulder, wrist, and finger joints against minimal pressure (3+ to 4-/5) 
and her elbow joint against moderate pressure (4/5).

\section{Range of motion of extremity joints.}

Goniometric measurements indicated that the range of active supination/pronation and flexion/extension of the elbow, wrist, and finger joints of both upper extremities was normal. External and internal rotations, abduction, adduction of both the shoulder joints were normal. Extension and flexion of both knee joints were in normal range but the flexion of left hip joint was restricted to 20 degrees. Passive ROM of the joints of all 4 extremities was normal.

\section{Ayurvedic Management}

As she develops the acute attack of left sided hemiparesis and right sided facial paralysis after delivery (she had delivered a male baby on 9/08/2014 at 4am and on same day at 11 am she got CVA), it belongs to 'Sutikajannya Vyadhi' (post- puerperal disease).

Charaka, Sushruta and Vagbhatta all have given the principles of treatment for puerperal disorders after indicating that these are incurable or are cured with greater difficulty. Puerperal disorders are described in details by Acharya Kashyapa. Since all the dhatus (tissues) depleted and become languid or unsteady due to expulsion of foetus, body become empty due to excretion of blood and the patient exhausted with labour pain, her digestive power, muscle mass and strength decreases, all the disease occurs due to Aptarpana (depletion due to expulsion of blood etc., body tissues) and purifying procedures (Panchakarma) can't be given, hence the disease developing during this stage become incurable or get cured with difficulty. Achaya Kashyapa has described puerperal diseases at two different places one in 'Dusprajatachikitsadhyaya' where he doesn't mentioned any exact number and described thirty-five disorders and again in 'Sutikopakarmaniya adhyaya' he described sixty- five disorders. Twenty five diseases have been enumerated at both the places while other differs. Thus the total number of puerperal disorders collectively described at both places is seventy four. Among these seventy four diseases he mentioned akshiroga (eye disorders), kamp or vepathu (tremors) and ardita (facial paralysis) present in the patient. Acharya Charaka says that disorders like aptanaka (tetanus), ardita (facial paralysis), etc developing after delivery should be managed according to the treatment principles described in general medicine. Acharya Sushruta described ardita (facial paralysis) in puerperal woman.
In puerperal disease there is dhatukshaya (mainly rakta= blood) and thus there is mainly vitiation of Vata as manifested in this case as nystagmus, ataxia, etc. Thus the first consideration is given to pacify Vata with the help of medicines and Panchakarma therapies.

\section{Plan of Management:}

A. Drug therapy

B. Panchakarma therapy -
i. Nasya
ii. Tarpana
iii. Patra Pinda Pottali Svedana

\section{Drug therapy}

- Vr. Vatacintamani rasa - 125mg twice in $\left.\begin{array}{ll}\text { Svarnamashika bhasma }-250 \mathrm{mg} \\ \text { Pravala pista } & -125 \mathrm{mg}\end{array}\right\} \begin{aligned} & \text { with } \\ & \text { madhu }\end{aligned}$

- Saptamrita Lauha - 2 tab twice in a day with milk/water

- Arjunarista + Lauhasava - 2 TSF from each with equal amount of water

- Dashmula kwatha - 10g (in decoction form) twice in a day added with Eranda taila (1 TSF)

- Aswangandhavleha - 1 TSF twice in a day with milk

As mentioned above this is a case of post- puerperal disease (Sutikajanya vyadhi) and Vatashamaka medicines has to given in this case so drug of choice is Sutikabharana rasa but due to its unavailability, Vr. Vatacintamani rasa is chosen. Vr. Vatacintamani rasa has 3 parts Svarrna bhasma, 2 parts Rajat and Abhraka bhasma with 5 parts Lauha and 7 parts Rasasindura. Svarna bhasma along with abhraka bhasma replenishes the depleted dhatus and 7 part rasasindura due to its sukshma guna helps to remove obstruction from micro-channels, Raupya bhasma act as nerve tonic, Pravala bhasma, Mukta bhasma and Lauha bhasma helps in repairing the damaged capillary endothelium and restoring blood circulation (by virtue of their Kashaya rasa and Sita guna these all cause vasoconstriction and helps in preventing blood loss). As Vata is vitiated due to excessive loss of Rakta dhatu, the next consideration is 
given to replenish and restoring blood loss. Arjunarista with Lauhasava acts simultaneously on Raktavaha srotasa and Raktavaha srotamula adjuvant with Saptamrita Lauha ( having triphala and madhuyasti along with lauha bhama) is helpful in replenishing iron depletion (Rakta dhatu). Dashamula decoction along with castor oil helps in Vatanuloman ( clear the lumen and helps in maintaining biotic flora of the gut thereby reducing the toxin to cross BBB). Aswagandha by virtue of its balya (providing strength), and brihaniya guna helps in restoring muscle power.

\section{Panchakarma therapy}

Nasya therapy: Nose is said to be the gateway of brain in Ayurveda. Nasal delivery of drug is the best route in patients with This is due to the large surface area, porous endothelial membrane, high total blood flow, the avoidance of first-pass metabolism, and ready accessibility. Drugs are cleared rapidly from the nasal cavity after intranasal administration, resulting in rapid systemic drug absorption. Ghrita due to its bio-adhesive or more appropriately muco-adhesive property absorbed easily.

Aswagandha Ghritam (Bhaisajya Ratnavali: Vajikarana; 288-298) It contains cow ghrita, cow milk, aswangandha, kakoli, ksirakakoli, riddhi, meda, mahameda, jivaka, atmagupta, risabhaka, yasthi, draksa, mandukaparni, masaparni, jivanti, pippali, bala, satavari, vidari kand, jiggery and honey. According to Bhaisajya Ratnavali, this ghrita is useful in timira (eye disorder), khalitya (alopecia), palitya (greying of hairs), and severe diseases and in those who have weak sensual power. Aswagandha, also known as Indian Ginseng is a wonderful nerve and muscle tonic According to the Ayurvedic system, Ashwagandha is the best herb for balancing Vata in the body. Vata governs all movement in the body, including the movement of nerve impulses throughout the nervous system. As the patient was diagnosed as the case of hemorrhagic leukoencephalitis/ acute disseminated encephalomyelitis (ADEM) which is a autoimmune disease destructing myelin sheath, Aswagandha ghrita was chosen because Aswagandha is reported to have immunomodulator effect and anti-oxidant activity. W. somnifera showed potent inhibitory activity towards the complement system, mitogen induced lymphocyte proliferation and delayed-type hypersensitivity reaction. Researchers report immunosuppressive effect of $\mathbf{W}$. somnifera root powder, thus it could be a candidate for developing as an immunosuppressive drug for the inflammatory diseases ${ }^{1}$.
Neurological conditions that have been studied in animal models that could benefit from nose-to-brain delivery of nanotherapeutics include pain, epilepsy, neurodegenerative disease and infectious diseases. The delivery of drugs to the brain via the nose-tobrain route holds great promise, on the basis of preclinical research by means of drug delivery systems such as polymeric nanoparticles and clinical data related to intranasal delivery to CNS of large molecular weight biologics administered in solution, but safety issues about toxicity on nasal mucosa, $\mathrm{Np}$ transport into the brain, delivery only to specific brain regions and variability in the adsorbed dose still represent research topics that need to be considered, with a view of clinical translation of these delivery systems ${ }^{2}$.

Tarpana Therapy: Nystagmus (involuntary movement of eyes) is supposed to be caused by vitiation of Vata dosha, therefore Tarpana therapy is adopted. Tarpana means nourishment thus Tarpana therapy means providing nourishment to the eyes. In this therapy oil is poured in eyes and fill upto

Mahatriphaladya ghrita was selected for Tarpana in the present study, which was specially mentioned by Chakradatta in the context of Timira chikitsa. The ingredients of Ghrita are Haritaki (Terminalia chebula Rertz.), Bibhitaki (Terminalia bellirica Roxb.), Aamalaki (Emblica officinalis Gaertn.), Bhringaraja (Eclipta alba (L.) Hassk), Vasa (Adhatoda zeylanika Medic), Shatavari (Asparagus racemosus Willd.), Guduchi(Tinospora cordifolia), Pippali (Piper longum Linn.), Mishri, Draksha (Vitis vinifera Linn.), Neelakamala (Nelumbo nucifera), Yashtimadhu(Glycyrrhiza glabra Linn.), Kshirakakoli (Fritillaria roylei-Hook.f), Gambhari (Gmelina arborea Roxb.), Kantakari (Solanum surratense), Ghrita (ghee), and goat milk.

\section{Procedure of Netra-Tarpan}

- Snehan with til tail and aardra swed (wet sudation) was given at shira (frontal part of the head), ganda (cheeks region)and manya pradesh (neck region) to the patient before Netra-tarpan.

- Dough was prepared using flour of Udad dal, which was used to prepare Pali around eye for Netra-tarpan.

- Triphala Ghrit was made luke warm in steel container with the help of hot water. Then it was gently poured with spoon in the Netra 
pali from apang or kaninika sandhi (lateral canthus or medial canthus). Pouring of Mahatriphala Ghrit directly on karnika (cornea) was strictly avoided.

- Mahatriphala ghrit was poured till eye lash merge in Ghrit.

- Patient was asked to blink gently so that Mahatriphala-ghrit should reach every part of eye.

- Luke warmness of Mahatriphala-ghrit was maintained by removing old and adding fresh luke warm Mahatriphala-ghrit time to time as per season.

- The procedure of Netra-Tarpan was carried for 10 to 15 minutes.

- After that Mahatriphala-ghrit was removed from netra pali and pali was also removed and patient was asked to wash eyes with luke warm water.

- Patient was advised to use sun-goggle to avoid contact of dust, air and pollution.

\section{Duration of therapy:}

- 10 to 15 minutes duration Netra-tarpan daily.

\section{Probable Mode of Action:}

Triphala and ghrit both are having Netrya property. Ghrit contains K2 and lionelic acid. It is having anti-inflammatory and anti-cancer property. Ghrit is also rich in vitamin A. Suplimentation of Vitamin $A$ reduces and treats dryness which occurs due to its deficiency. In Netra-tarpan all these properties nourishes the conjunctival as well as corneal layers and avoid dryness and inflammation of tissue of conjunctiva and cornea. Thus helps to avoid dryness of eyes also gives smoothening to layers of conjunctiva and cornea. Its Chakshushya guna improves the health status of eyes. External application of Ghrita is supposed to pacify Vata dosha, potentiates ocular muscles and thereby improve their movements.

\section{Evaluation}

Functional Independence Measure Scale was used for assessing the improvement. The FIM is widely used scale that yields valid and reliable measurements of mobility, self-care, locomotion, communication, sphincter management, and social cognition. ${ }^{1-2}$
Its 7-level scale ranges from "total dependence" $(0)$ to "complete independence" (7). Patient bed mobility improved from requiring moderate assistance (2/7) to requiring mild assistance (3/7). Transfers improved from requiring maximal assistance $(2 / 7)$ to requiring moderate assistance (3/7). Walking improved from complete dependence on walker (1/7) to requiring moderate to maximal assistance (2.5/7). Grooming, bathing, toileting, and upper-and lower-body dressing improved from requiring maximal assistance (1.7/7) to requiring moderate to maximal assistance (2.5/7). There was significant improvement in functional activity of the patient in 15 days duration of treatment.

The functional limitation experienced by the patient is due to both motor and somatosensory impairments as a result of hemorrhagic stroke in the medial pontine tegmentum. Patient abnormalities in control of posture and whole-body movements was most likely reflected combined damage to medial brain-stem and ascending somatosensory systems. Some residual control of the right hand and fingers and, to a lesser extent, the left hand and fingers remained, which probably reflected sparing of corticospinal tracts.

Assessment for improvement in balance was done by using "Berg Balance Scale". This balance scale1 is based on 14 items that are common to daily life activities. The items include both simple mobility tasks (transfers, standing unsupported, sit to stand) and more diffi cult tasks (tandem standing, turning through 360 degrees, single leg stance). The items are graded on a 5-point ordinal scale from 0 to 4, with a maximum possible score of 56 points. A score of 0 is given if the participant is unable to perform the task, and a score of 4 is given if they are able to do the task (table 1.1)

Assessment of improvement in Nystagmus: There was improvement in the amplitude and speed of nystagmus during the course of treatment. At the time of hospitalization the patient had fast $(>100$ jerks/ minute) and fine $(<1 \mathrm{~mm})$ nystagmus and at the time of discharge she had slow $(<40$ jerks/ minute) and coarse nystamus ( $>3 \mathrm{~mm}$ ). As the duration of trial was only 15 days so marked changes were not observed but the most interesting fact observed was that she regains the medial side vision i.e scotoma diminished. Though it is difficult to explain exactly how it occurs but it showed that there is probably regeneration of optic tract.

\section{Intervention and Outcomes}

In the above case the patient came to seek Ayurve- 
dic treatment one year after the stroke, so we have to manage the residual paralysis. The treatment plan was prepared considering the need to manage the disability and improve the quality of life. Considering the Ayurvedic principles of management the treatment plan was prepared incorporating both medicinal and Panchakarma measures. Acharya Charaka says that ailment affecting upper body parts (eg. Head, neck, eyes, ears et.) should be treated with Nasya therapy. According to Ayurveda "Nasa hi Shirsodvarma" i.e nose is the doorway to brain. As there was Chakshuvibhram (nystagmus) which is supposed to be due to vitiated Vata (increased Vata dosha due to dhatukshaya), Ashwagandha ghrita was chosen for nasal insufflation. Administration of Aswangandha ghrita by nose is a type of Tarpana Nasya that nourishes the depleted Tarpak Kapha and nurture the Alochka Pitta. Tarpana with Mahatriphala Ghrita helps in revitalising ocular muscle and potentiate their movements. Medicinal treatment helps in dislodging the vitiated doshas from the srotas and re-establishing the Agni. As this is the case of hemorrhagic leukoencephalitis which is a rare and a fatal disease therefore the expected outcome was supposed to be not very significant but on contrary to that after 15 days of treatment the patient showed significant improvement in every feature of disease including nystagmus and ataxia. Though the improvements are very slow and nuanced but even then these changes gives a positive attitude to the patient and hope that soon she will get recovered completely. The quality of life was remarkably improved during her hospital stay. When she came she used to cry usually because of the social stigma she had to face related to her delivery, the misbehaviour of her husband and mother in-law, but with the progressive treatment and improvement she attained the self confidence. Though the patient was discharged after 15 days of treatment but she was instructed to readmit after one month to take basti treatment. During this period she was advised to take following medicines: Ekagveer rasa - 2 tab twice in a day with Dashmula kwath $(10 \mathrm{gm})$ added with castor oil-1 TSF, Tapyadi lauha- 2 tab twice in a day, Arjunarista + Lauhasava (2 TSF/ each with equal amount of water) twice in a day after meal, Aswagandhavleha - 1 TSF twice in a day with luke warm milk.

In summary, during the 15 days of treatment, the patient regained her ability to effectively communicate her needs and wishes, thereby restoring control over many aspects of her daily life. Mobility and ability to perform self-care activities improved to the point that she required little assistance of 1 person occasionally rather than always. The observed result are encouraging and gives a hope that if patient will take proper treatment she may recover functionally.

Conclusion: Therapeutic interventions aimed at optimizing the residual disability and postural abnormalities along with nystagmus seems to be fruitful in management of post stroke patients. This case suggests that Ayurvedic therapies can significantly rehabilitate the post traumatic nerve injuries and help in revitalizing the muscular tone and also prevent the autoimmune cascade from producing inflammatory damage. Ayurvedic treatment produces slow and static improvement in the entire three components of disease and the most marked effect was seen on postural disability.

\section{Appendix:}

\section{Functional Improvement Measurement Scale}

\section{A. Self-care}

1. Eating

2. Grooming

3. Bathing/showering

4. Dressing upper body

5. Dressing lower body

6. Toileting

7. Swallowing

\section{B. Sphincters}

1. Bladder management

2. Bowel management

C. Mobility

1. Transfers: bed/chair/wheelchair

2. Transfers: toilet

3. Transfers: bathtub/shower

4. Transfers: car

5. Locomotion: walking/wheelchair

6. Locomotion: stairs

7. Community mobility 
Divya, JSR, 2016; Vol. 1(1): 0001-0012
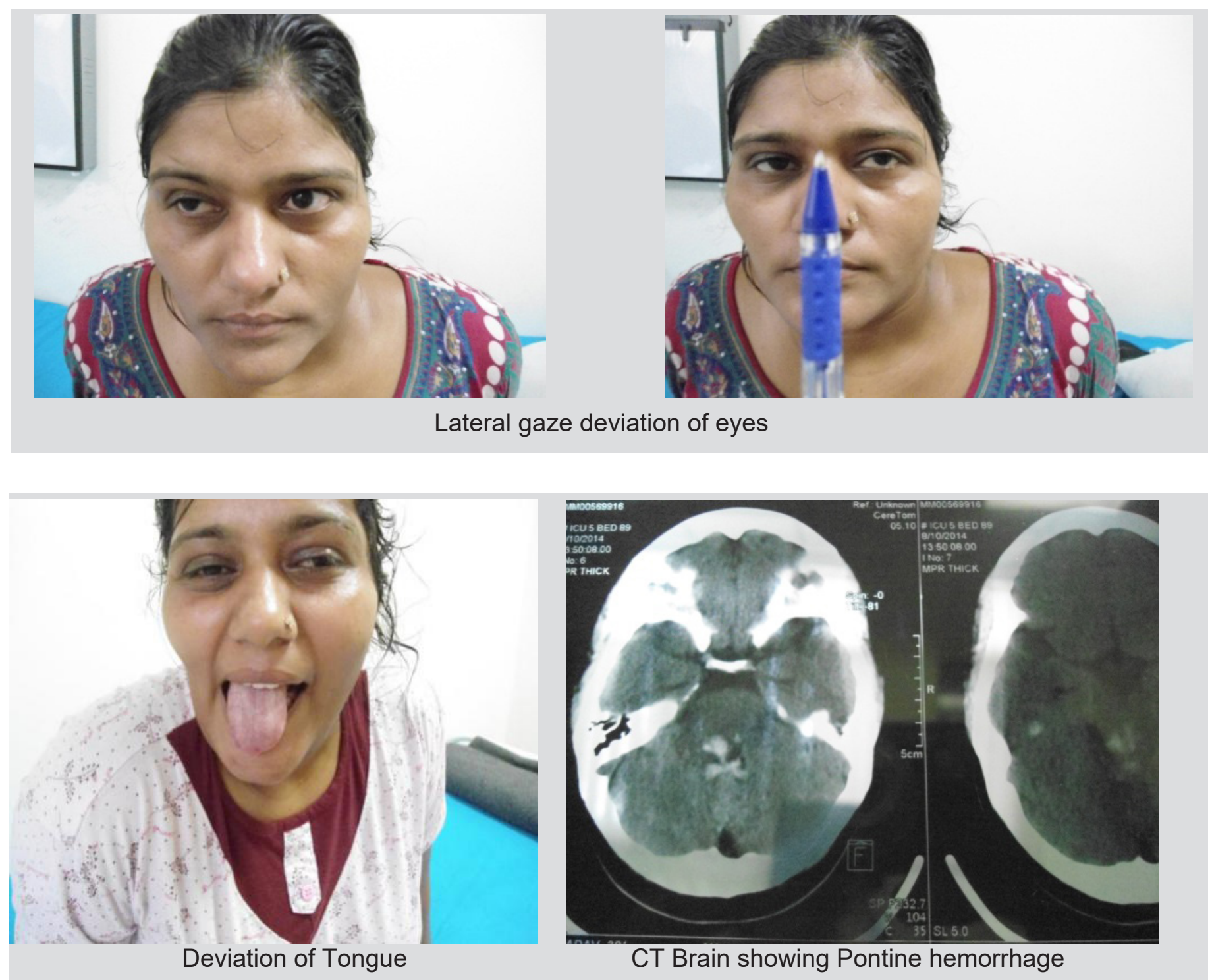

CT Brain showing Pontine hemorrhage

\section{Seven levels for each item}

\begin{tabular}{|c|c|c|}
\hline & Level & Description \\
\hline 7 & Complete independence & Fully independent \\
\hline 6 & Modifi ed independence & Requiring the use of a device but no physical help \\
\hline & Supervision & $\begin{array}{l}\text { Requiring only standby assistance or verbal prompting or help } \\
\text { with set-up }\end{array}$ \\
\hline & Minimal assistance & $\begin{array}{l}\text { Requiring incidental hands-on help only (subject performs }> \\
75 \% \text { of the task) }\end{array}$ \\
\hline & Moderate assistance & Subject still performs $50-75 \%$ of the task \\
\hline & Maximal assistance & Subject provides less than half of the effort (25-49\%) \\
\hline & Total assistance & $\begin{array}{l}\text { Subject contributes }<25 \% \text { of the effort or is unable to do the } \\
\text { task }\end{array}$ \\
\hline
\end{tabular}




\section{Communication}

1. Expression

2. Comprehension

3. Reading

4. Writing

5. Speech intelligibility Psychosocial

6. Social interaction

7. Emotional status

8. Adjustment to limitations

9. Use of leisure time (replaces employability in original version) Cognition

10. Problem solving

11. Memory

12. Orientation

13. Concentration (replaces attention in original version)

14. Safety awareness (replaces safety judgement in original version)

\section{BERG BALANCE SCALE}

\section{Sitting to standing}

Try not to use your hands for support. Able to stand, not using hands, and stabilise independently $=4$ points

Able to stand independently using hands $=3$ points Able to stand using hands after several tries $=2$ points

Needs minimal assistance to stand and stabilise $=1$ point

Needs moderate or maximal assistance to stand $=0$ points

\section{Standing unsupported}

Stand for 2 minutes without holding on to support. Able to stand safely for 2 minutes = 4 points

Able to stand for 2 minutes with supervision $=3$ points
Able to stand for 30 seconds, unsupported $=$ 2 points

Needs several tries to stand for 30 seconds, unsupported $=1$ point

Unable to stand for 30 seconds, unassisted $=0$ points

\section{Sitting unsupported, with feet on floor}

Sit with arms folded for 2 minutes. Able to sit safely and securely for 2 minutes $=4$ points Able to sit for 2 minutes under supervision = 3 points

Able to sit for 30 seconds $=2$ points Able to sit for 10 seconds $=1$ point

Unable to sit unsupported $=0$ points

\section{Standing to sitting}

Sits safely with minimal use of hands $=4$ points

Controls descent by using hands $=3$ points

Uses backs of legs against chair to control descent $=2$ points

Sits independently but has uncontrolled descent $=1$ point

Needs assistance to sit down $=0$ points

\section{Transfers}

One way towards a seat with armrests. One way towards a seat without armrests.

Able to transfer safely with minimal use of hands $=4$ points

Able to transfer safely with defi nite use of hands $=3$ points

Able to transfer safely with verbal cueing and/or supervision $=2$ points

Needs assistance of one person $=1$ point

Needs assistance of two people to transfer safely/unable to transfer $=0$ points

\section{Standing unsupported with eyes closed}

Close your eyes and stand still for 10 
seconds. Able to stand still for 10 seconds safely $=4$ points

Able to stand still for 10 seconds with supervision $=3$ points

Able to stand still for 3 seconds $=2$ points

Unable to keep eyes closed for 3 seconds, but stays steady $=1$ point

Needs help to keep from falling $=0$ points

\section{Standing unsupported with feet together}

Able to place feet together independently and stand safely for 1 minute $=4$ points

Able to place feet together independently and stand for 1 minute with supervision $=3$ points

Able to place feet together independently, but unable to hold for 30 seconds $=2$ points Needs help to attain position, but able to stand for 15 seconds $=1$ point

Needs help to attain position, and unable to hold for 15 seconds $=0$ points

\section{Reaching forward with outstretched arm}

Can reach forward confi dently more than 10 inches $=4$ points

Can reach forward more than 5 inches $=3$ points

Can reach forward more than 2 inches $=2$ points

Reaches forward, but needs supervision $=1$ point

Needs help to keep from falling $=0$ points

\section{Picking up item from floor}

Able to pick up the slipper safely and easily $=4$ points

Able to pick up the slipper, but needs supervision, and keeps balance independently $=3$ points

Unable to pick up the slipper, reaches 2-3 inches from it $=2$ points
Unable to pick up the slipper, and needs supervision when trying $=1$ point

Unable to pick up the slipper, and needs assistance to keep from falling $=0$ points

10. Turning to look behind over left and right shoulder

Looks behind from both sides and shifts weight well $=4$ points

Looks behind to one side only, other side shows less weight shift $=3$ points

Turns sideways only, but maintains balance $=2$ points

Needs supervision when turning $=1$ point Needs assistance to keep from falling $=0$ points

\section{Turning through 360 degrees}

Able to turn through 360 o safely each way in less than 4 seconds $=4$ points

Able to turn through 360 o safely to one side in less than 4 seconds $=3$ points

Able to turn through 360 o safely but slowly $=$ 2 points

Needs close supervision or verbal cueing $=$ 1 point

Needs assistance while turning $=0$ points

\section{Number of times stool touched while} stepping

Able to stand independently and safely and complete 8 steps in 20 seconds $=4$ points

Able to stand independently and complete 8 steps in 20 seconds $=3$ points

Able to complete 4 steps, without aid, with supervision $=2$ points

Able to complete more than 2 steps, needs minimal assistance $=1$ point

Needs assistance to keep from falling/ unable to try $=0$ points

\section{Standing unsupported with one foot in}




\section{front of the other}

Able to place feet in tandem independently and hold for 30 seconds $=4$ points

Able to place one foot in front of the other independently and hold for 30 seconds $=3$ points Able to take small step independently and hold for 30 seconds $=2$ points

Needs help to step, but can hold for 15 seconds $=1$ point

Loses balance while stepping or standing $=$ 0 points

\section{Standing on one leg}

Able to lift leg independently and hold for 10 seconds $=4$ points

Able to lift leg independently and hold for $5-10$ seconds $=3$ points

Able to lift leg for more than 3 seconds $=2$ points

Tries to lift leg, unable to hold for 3 seconds, but remains standing independently $=1$ point Unable to try, or needs assistance to prevent falling $=0$ points Total score

( maximum possible score $=56$ )

Acknowledgement: Dr. Riju Aggrawal sincere help in carrying out ophthalmological examinations and concluding drug intervention is acknowledging.

\section{References}

1. Oczkowski WJ, Barreca S. The functional independence measure: its use to identify rehabilitation needs in stroke survivors. Arch Phys Med Rehabil.1993 ;74:1291-1294.

2. Hamilton BB, Laughlin JA, Fiedler RC, Granger CV. Interrater reliability of the 7-level functional independence measure (FIM). Scand J Rehabil Med.1994 ;26:115-119.

3. Stineman MG, Jette A, Fiedler $R$, Granger C. Impairment-specific dimensions within the Functional Independence Measure. Arch Phys Med Rehabil.1997 ;78:636-643.

4. Stineman MG, Shea JA, Jette A, et al. The Functional Independence Measure: tests of scaling assumptions, structure, and reliability across 20 diverse impairment categories. Arch Phys Med Rehabil.1996 ;77:1101-1108.

5. Rasool M., Varalakshmi P. Immunomodulatory role of Withania somnifera root powder on experimental induced inflammation: An in vivo and in vitro study. Vascular Pharmacology. 2006; 44 (6): 406-410.

6. Ong WY, Shalini SM, Costantino L.Nose-to-brain drug deliverybynanoparticlesinthetreatmentofneurological disorders. Curr Med Chem. 2014;21(37):4247-56.

7. Hamilton BB, Granger CV, Sherwin FS et al. A uniform national data system for medical rehabilitation. In: Fuhrer MJ, editor. Rehabilitation Outcomes: analysis and measurement. Baltimore, MD: Brookes; 1987. pp. 137-47.

8. StinemanMG, JetteA, FiedlerRetal.Impairment-specifi c dimensions within the Functional Independence Measure. Arch Phys Med Rehabil. 1997; 78: 636-43.

9. Hall KM, Mann N, High WM et al. Functional measures after traumatic brain injury: ceiling effects of FIM, FIM+FAM, DRS and CIQ. J Head Trauma Rehabil. 1996; 11: 27-39.

10. Turner-Stokes $\mathrm{L}$, Nyein $\mathrm{K}$, Turner-Stokes $\mathrm{T}$ et al. The UK FIM+FAM: development and evaluation. Clin Rehabil. 1999; 13: 277-87.

11. Berg KO, Wood-Dauphinee SL, Williams $\mathrm{Jl}$ et al. Measuring balance in the elderly: preliminary development of an instrument. Physiother Can. 1989; 41: 304-11.

12. Berg KO, Wood-Dauphinee SL, Williams Jl. The balance scale: reliability assessment with elderly residents and patients with an acute stroke. Scand J Rehabil Med. 1995; 27: 27-36.

13. Berg KO, Maki BE, Williams Jl et al. Clinical and laboratory measures of postural balance in an elderly population. Arch Phys Med Rehabil. 1992;73:1073-80.

14. Thorbahn LDB, Newton RA. Use of the Berg balance test to predict falls in elderly persons. Phys Ther. 1996; 76: 576-83.

15. Harada N, Chiu V, Damron-Rodriguez J et al. Screening for balance and mobility impairment in elderly individuals living in residential care facilities. Phys Ther. 1995; 75: 462-9.

16. Riddle DL, Startford PW. Interpreting validity indexes 
for diagnostic tests: an illustration using the Berg balance test. Phys Ther. 1999; 79: 939-48. 7 Newton R. Balance screening of an inner-city older adult population. Arch Phys Med Rehabil. 1997; 78: 587-91.

Table 1.1: Berg Balance Scale for assessment of balance

\begin{tabular}{|c|c|c|c|}
\hline \multirow[t]{2}{*}{ S.No } & \multirow[t]{2}{*}{ Level } & \multicolumn{2}{|r|}{ Score } \\
\hline & & Before Treatment & After Treatment \\
\hline 1. & Sitting to standing & $\begin{array}{l}0 \text { (unable to stand without } \\
\text { support) }\end{array}$ & 2 (able to stand using hands after several tries) \\
\hline 2. & Standing unsupported & $\begin{array}{c}0 \text { (unable to stand for } 30 \text { sec- } \\
\text { onds, unassisted) }\end{array}$ & 3 (able to stand for 2 minutes with supervision) \\
\hline 3. & $\begin{array}{l}\text { Sitting unsupported, with feet on } \\
\text { floor }\end{array}$ & $\begin{array}{l}4 \text { (able to sit safely and se- } \\
\text { curely for } 2 \text { minutes) }\end{array}$ & 4 (able to sit safely and securely for 2 minutes) \\
\hline 4. & Standing to sitting & $\begin{array}{l}1 \text { (sits independently but has } \\
\text { uncontrolled descent) }\end{array}$ & 3 (controls descent by using hands) \\
\hline 5. & Transfer & $\begin{array}{l}1 \text { (needs assistance of one } \\
\text { person) }\end{array}$ & $\begin{array}{l}3 \text { (able to transfer safely with definite use of } \\
\text { hands) }\end{array}$ \\
\hline 6. & $\begin{array}{l}\text { Standing unsupported with eyes } \\
\text { closed }\end{array}$ & $\begin{array}{l}0 \text { (needs help to keep from } \\
\text { falling) }\end{array}$ & 2 (able to stand still for 3 seconds) \\
\hline 7. & $\begin{array}{l}\text { Standing unsupported with feet } \\
\text { together }\end{array}$ & $\begin{array}{l}0 \text { (needs help to attain posi- } \\
\text { tion, and unable to hold for } 15 \\
\text { seconds) }\end{array}$ & $\begin{array}{l}1 \text { (needs help to attain position, but able to stand } \\
\text { for } 15 \text { seconds) }\end{array}$ \\
\hline 8. & $\begin{array}{l}\text { Reaching forward with out- } \\
\text { stretched arms }\end{array}$ & $\begin{array}{l}0 \text { (needs help to keep from } \\
\text { falling) }\end{array}$ & ( reaches forward, but needs supervision) \\
\hline 9. & Picking up item from floor & $\begin{array}{l}0 \text { (unable to pick up the slip- } \\
\text { per, and needs assistance to } \\
\text { keep from falling) }\end{array}$ & $\begin{array}{l}3 \text { (able to pick up the slipper, but needs super- } \\
\text { vision) }\end{array}$ \\
\hline 10. & $\begin{array}{l}\text { Turning to look behind over left } \\
\text { and right shoulder }\end{array}$ & $\begin{array}{l}0 \text { (needs assistance to keep } \\
\text { from falling) }\end{array}$ & 1 (needs supervision when turning) \\
\hline 11. & Turning through 360 degrees & $\begin{array}{l}0 \text { (needs assistance while } \\
\text { turning) }\end{array}$ & 0 (needs assistance while turning) \\
\hline 12. & $\begin{array}{l}\text { Number of times stool touched } \\
\text { while stepping }\end{array}$ & $\begin{array}{l}0 \text { (needs assistance to keep } \\
\text { from falling/unable to try) }\end{array}$ & $\begin{array}{l}1 \text { (able to complete more than } 2 \text { steps, needs } \\
\text { minimal assistance) }\end{array}$ \\
\hline 13. & $\begin{array}{l}\text { Standing unsupported with one } \\
\text { foot in front of the other }\end{array}$ & $\begin{array}{l}0 \text { (loses balance while step- } \\
\text { ping or standing) }\end{array}$ & 0 (loses balance while stepping or standing) \\
\hline 14. & Standing on one leg & $\begin{array}{l}0 \text { (unable to try, or needs as- } \\
\text { sistance to prevent falling) }\end{array}$ & $\begin{array}{l}0 \text { (unable to try, or needs assistance to prevent } \\
\text { falling) }\end{array}$ \\
\hline
\end{tabular}
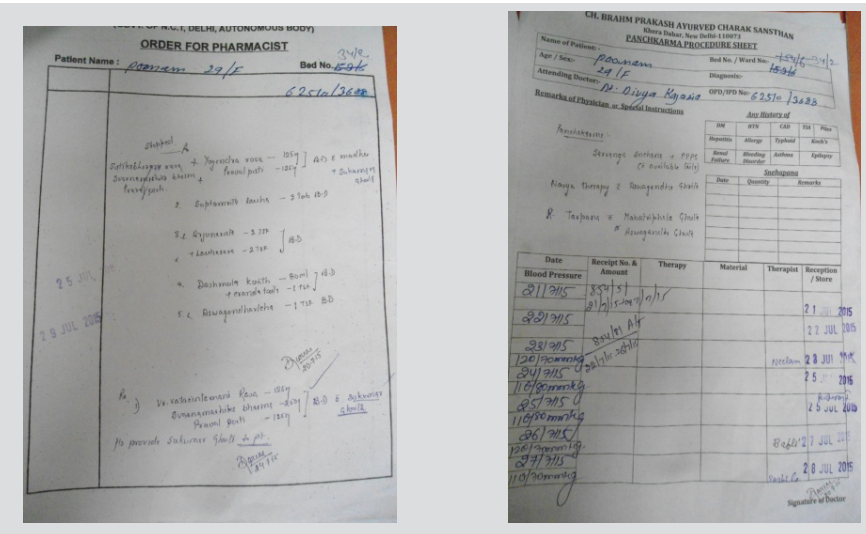

Indoor admission drug list and Panchakarma procedures sheet 